\title{
PENERAPAN LESSON STUDY DALAM MENINGKATKAN KOMPETENSI PEDAGOGI GURU SMA BINA MULYA GADINGREJO \\ TAHUN PELAJARAN 2015/2016
}

\author{
Heri Supranoto \\ Pendidikan Ekonomi FKIP Universitas Muhammadiyah Metro \\ Heri_supranoto@yahoo.com
}

\begin{abstract}
Abstrak
Guru merupakan salah satu ujung tombak keberhasilan tujuan dari pendidikan. Guru merupakan komponen paling menentukan dalam sistem pendidikan secara keseluruhan yang harus mendapat perhatian sentral, pertama dan utama. Figur yang satu ini akan senantiasa menjadi sorotan strategis ketika berbicara masalah pendidikan, karena guru selalu terkait dengan komponen manapun dalam sistem pendidikan. Guru memegang peran utama dalam pembangunan pendidikan, khususnya yang diselenggarakan secara formal di sekolah.

Lesson Study diartikan sebagai suatu model pembinaan profesi pendidik melalui pengkajian pembelajaran secara kolaboratif dan berkelanjutan, berdasarkan prinsip-prinsip kolegialitas yang saling membantu dalam pembelajaran untuk membangun komunitas belajar. Adapun tujuan utama dari penggunaan metode Lesson Study adalah kegiatan perbaikan guru dalam melakukan proses pembelajaran di kelas. Hal ini susuai dengan pendapat Astika (2013: 04), yang mengatakan bahwa: Lesson Study mendukung terjadinya peningkatan kemampuan profesionalisme guru, khususnya kompetensi pedagogi dan kompetensi profesional. Teknik pengajaran yang dilakukan dengan berbagai ketrampilan bertujuan untuk menciptakan situasi dalam proses belajar mengajar, yakni dapat menyenangkan dan mendukung terciptanya prestasi belajar siswa yang memuaskan.
\end{abstract}

Dengan adanya proses pembelajaran berbasis Lesson Study, diharapkan guru akan mengetahui kelamahan-kelamahan yang selama ini dilakukan saat dikelas dan berusaha memperbaikinya dipertemuan berikutnya melalui pengamatan yang dilakukan oleh guru lain.

Kata Kunci: Lesson Study dan Kompetensi Pedagogi Guru

\section{PENDAHULUAN}

Realita sekarang banyak guru yang pintar tetapi belum dapat mentransfer ilmunya kepada peserta didik, belum mampu mengkondisikannya di saat pembelajaran serta cara penyampaian kurang tepat. Hai inilah yang mengakibatkan motivasi belajar peseta didik kurang maksimal. Padahal dijelaskan oleh Syaiful (2009: 32), bahwa "guru yang mempunyai kompetensi pedagogik akan dapat meningkatkan motivasi peserta didik."

Berdasarkan hasil PKG (Penilaian Kinerja Guru) di SMA Bina Mulya tahun 2014, masih ada beberpa guru yang nilainya kurang memuaskan, salah satunya adalah saat melakukan proses pembelajaran di kelas, masih ditemukan pengelolaan kelas yang kurang efektif, selain itu masih ditemukan beberapa guru 
yang dalam melakukan proses pembelajaran kurang persiapan. Hal itu terbukti dari RPP guru yang tidak semua memiliki dan lembar kerja siswa yang tidak dimiliki oleh guru.

Selain dari hasil PKG pengamatan secara langsung juga telah dilakukan, hasilnya pun tidak jauh berbeda dengan PKG yang dilakukan, ada sebagian guru yang saat masuk ke kelas terlambat beberapa menit kemudian keluar kelas lebih awal. Hal ini menunjukan bahwa kempuan guru atau kopentsi pedagogik guru masih rendah. Rendahnya kemepuan guru dalam mengelola kelas juga berdampak pada sikap siswa. Ada bebrapa siswa yang tidak tertarik dengan materi yang diberikan oleh guru. Hal itu terbukti dari masih adanya siswa yang mainan HP saat dikelas, seringnya izin keluar dengan alasan yang tidak jelas dan masih adanya siswa yang ribut sendiri dengan siswa.

Menindak lanjuti hal tersebut, maka saya sebagai kepala sekolah perlu melakukan inovasi dalam proses pembelajaran di kelas. Adapaun inovasi yang telah saya lakukan adalah pembelajaran menggunakan metode Lesson Study.

\section{KAJIAN PUSTAKA}

\section{Pengertian Lesson Study}

Menurut Hendrayana (2007: 10) Lesson Study adalah suatu model pembinaan profesi pendidik melalui pengkajian pembelajaran secara kolaborarif dan berkelanjutan berlandasan prinsip-prinsip kolegalitas dan mutual learning untuk membangun komunitas belajar.

Adapun Lesson Study menurut Rusman (2010: 384) merupakan kegiatan yang dapat mendorong terbentuknya sebuah komunitas belajar (learning society) yang secara konsisten dan sistematis melakukan perbaikan diri, baik pada tataran individual maupun manajerial.

Mulyana (2007) menyebutkan bahwa: "ada dua bentuk Lesson Study yang dapat dilaksanakan di Indonesia, yaitu:

1. Lesson Study berbasis Musyawarah Guru Mata Pelajaran (MGMP), yakni Lesson Study yang dilaksanakan pada setiap hari pertemuan MGMP yang telah ditetapkan. Kegiatan yang dilakukan meliputi Plan pada minggu pertama, do pada minggu kedua, dan See pada minggu ketiga.

2. Lesson Study berbasis sekolah (LSBS), yakni Lesson Study yang dilakukan di suatu sekolah dengan kegiatan utama berupa open lesson atau open class oleh setiap guru secara bergiliran pada hari tertentu.

Bentuk Lesson Study manapun yang menjadi pilihan bagi seorang guru tidak menjadi masalah asalkan dilakukan sesuai dengan tahapan-tahapan yang telah ditentukan.

Menurut Hidayat (2015: 05) Langkahlangkah Lesson Study adalah

a. Perencanan (Plan) 
Perencanaan dilakukan secara kolaboratif berdasarkan permasalahan di kelas untuk mengembangan model pembelajaran yang berpusat pada siswa melalui hands-on \& minds-on activity, daily life, and local materials. Secara umum kegiatan Plan berupa penggalian akademik, perencanaan pembelajaran dan penyiapan alat-alat. Perencanaan pembelajaran dilakukan dengan memperhatikan tujuan pembelajaran dan karakteristik serta perkembangan siswa, yang dilakukan secara koligeal dan kolaboratif. Perencanaan bisa juga dilakukan dengan cara: dibuat oleh salah seorang guru kemudian dikonsultasikan/dipaparkan dihadapan rekan guru yang lain sehingga mendapat saran dan masukan untuk memperoleh perencanaan pembelajaran yang baik.

b. Pelaksanaan $(D o)$

Kegiatan $d o$ adalah kegiatan di mana seorang guru model melaksanakan pembelajaran di kelas, sedangkan guru yang lain melakukan pengamatan terhadap seluruh aktivitas belajar siswa selama proses pembelajaran berlangsung. Pengamatan juga dapat dilakukan oleh orang lain yang memiliki kepedulian terhadap pendidikan, dengan catatan sasaran pengamatan tidak ditujukan kepada guru, tetapi tertuju pada aktivitas siswa dalam mengikuti proses pembelajaran. Selama kegiatan $d o$ pengamat tidak diperkenankan membantu, menginterfensi, bertanya dan mengganggu siswa selama proses pembelajaran.

c. Refleksi (See)

Kegiatan refleksi dilakukan setelah kegiatan pembelajaran (do) selesai dilaksanakan, untuk melihat berbagai hal yang ditemukan dalam pelaksanaan pembelajaran, baik oleh guru model maupun para observer. Guru dan para observer melakukan sharing atas temuannya berkaitan dengan aktivitas belajar siswa selama proses pembelajaran. Observer dan guru model saling belajar dari pembelajaran yang telah diamati dan hasil sharing digunakan untuk merivisi rencana pembelajaran.

\section{Keunggulan Dan Kelemahan Lesson}

\section{Study}

Terlihat jelas bahwa Lesson Study ini memiliki banyak manfaat bagi guru. Susilo (2009) menyebutkan beberapa manfaat yang dirasakan oleh guru ketika mengikuti Lesson Study, seperti:

1. mengurangi keterasingan guru (dari komunitasnya) dalam perencanaan dan pelaksanaan pembelajaran dan perbaikannya

2. membantu guru untuk mengobservasi dan mengkritisi pembelajarannya

3. memperdalam pemahaman guru tentang materi pelajaran, cakupan dan urutan kurikulum

4. membantu guru memfokuskan bantuannya pada seluruh aktivitas belajar peserta didik

5. meningkatkan kolaborasi antar sesama guru dalam pembelajaran

6. meningkatkan mutu guru dan mutu pembelajaran yang pada gilirannya berakibat pada peningkatan mutu lulusan

7. memungkinkan guru memiliki banyak kesempatan untuk membuat bermakna ide-ide pendidikan dalam praktik pembelajarannya sehingga dapat mengubah perspektif tentang pembelajaran, dan belajar praktik pembelajaran dari perspektif peserta didik

8. mempermudah guru berkonsultasi kepada pakar dalam hal pembelajaran atau kesulitan materi pelajaran

9. memperbaiki praktik pembelajaran di kelas

10. meningkatkan keterampilan menulis karya tulis ilmiah atau buku ajar 
Menurut Susilo (2009), hambatan terbesar dalam pelaksanaan Lesson Study ini yaitu kurangnya pemahaman dan komitmen guru mengenai apa, mengapa, dan bagaimana melaksanakannya. Selain itu juga faktor budaya dan biaya. Hambatan budaya dan konteks merupakan salah satu hal yang harus diatasi dalam pelaksanaannya. Hambatan budaya yang berupa kecendrungan guru yang kurang memiliki komitmen dan kesungguhan hati untuk melakukan yang terbaik, kurang memiliki sikap "mau belajar sepanjang hayat", dan lebih tertarik melakukan sesuatu bila ada "biaya"nya. Hambatan lain yaitu kurang terbiasa mengembangkan budaya saling belajar dan membelajarkan secara kolaboratif dan kurang biasa melakukan refleksi diri secara kritis.

\section{Pengaruh Lesson Study dalam}

Meningkatkan Kemampuan Pedagogik

\section{Guru}

Lesson Study dilaksanankan dalam tiga tahapan yaitu Plan (merencanakan), Do (melaksanakan), dan See (merefleksi ) yang berkelanjutan. Dengan kata lain Lesson Study merupakan suatu cara peningkatan mutu pendidikan yang takpernah berakhir (continous improvement) (Hendayana, et al., 2006).

Astika (2013) Lesson Study mendukung terjadinya peningkatan kemampuan professionalisme guru, khususnya kompetensi pedagogi dan kompetensi profesional. Teknik pengajaran yang dilakukan dengan berbagai ketrampilan bertujuan untuk menciptakan situasi dalam proses belajar mengajar, yakni dapat menyenangkan dan mendukung terciptanya prestasi belajar siswa yang memuaskan.

\section{Kopetensi Pedagogik guru}

Rastodio (2009) mendefinisikan kompetensi guru sebagai penguasaan terhadap pengetahuan, keterampilan, nilai dan sikap yang direfleksikan dalam kebiasaan berpikir dan bertindak dalam menjalankan profesi sebagai guru.

Dalam Undang-Undang Guru dan Dosen No.14/2005 dan Peraturan Pemerintah No.19/2005, menetapkan standar kempuan guru sebagai berikut.

a. Kompetensi Kepribadian:

1) Mantap, stabil, dewasa, arif, bijaksana dan berwibawa.

2) Berakhlak mulia.

3) Menjadi teladan bagi peserta didik dan masyarakat

4) Mengevaluasi kinerja sendiri, dan

5) Mengembangkan diri secara berkelanjutan.

b. Kompetensi Paedagogik :

1) Pemahaman wawasan atau landasan pendidikan

2) Pemahaman terhadap peserta didik dan evaluasi belajar.

3) Pengembangan kurikulum/silabus

4) Perancangan pembelajaran serta Pelaksanaan pembelajaran yang mendidik

5) Pengembangan peserta didik untuk mengaktualisasikan berbagai potensi yang dimilikinya

c. Kompetensi profesional : 
1) Konsep struktur dan metode keilmuan/teknologi/seni yang menaungi/koheren dengan materi ajar

2) Materi ajar ada dalam kurikulum sekolah

3) Hubungan konsep antar mata pelajaran terkait

4) Penerapan konsep-konsep keilmuan dalam kehidupan sehari-hari, dan

5) Kompetensi secara professional dalam konteks global dengan tetap melestarikan nilai adan budaya nasional.

d. Kompetensi Sosial :

1) Berkomunikasi lisan dan tulisan

2) Menggunakan teknologi komunikasi dan informasi secara fungsional

3) Bergaul secara efektif dengan peserta didik sesama pendidik, tenaga kependidikan, orang tua/wali peserta didik, dan

4) Berbagai sikap secara santun dengan masyarakat sekitar.

Menurut Hasan (2003:57) ada beberapa factor penyebab rendahnya kompetensi profesional guru antara lain (a) Masih banyak guru yang tidak menekuni profesinya secara utuh. Hal ini disebabkan oleh banyak guru yang bekerja di luar jam kerjanya untukmemenuhi kebutuhan hidup sehari-hari sehingga waktu untuk membaca dan menulis untuk meningkatkan diri tidak ada; (b) Kemungkinan disebabkan oleh adanya perguruan tinggi swasta sebagai pencetak guru yang lulusannya asal jadi tanpa mempehitungkan outputnya kelak di lapangan sehingga menyebabkan banyak guru yang tidak patuh terhadap etika profesi keguruan; dan (d) Kurangnya motivasi guru dalam meningkatkan kualitas diri karena guru tidak dituntut untuk meneliti sebagaimana yang diberlakukan pada dosen di perguruan tinggi.

\section{Aspek Materi yang Dikembangkan}

\section{Dalam Inovasi}

a. Lesson Study Dalam Meningkatkan Kemapuan Pedagogi Guru

Menurut Syaiful (2009: 32) "Guru yang mempunyai kompetensi pedagogik akan dapat meningkatkan motivasi peserta didik. Sedangkan menurut (Standar Nasional Pendidikan, penjelasan Pasal 28 ayat 3 butir a) dalam Astika (2013: 04) "Kompetensi Pedagogi, adalah kemampuan mengelola pembelajaran peserta didik yang meliputi pemahaman terhadap peserta didik, perancangan dan pelaksanaan pembelajaran, evaluasi hasil belajar, dan pengembangan peserta didik untuk mengaktualisasikan berbagai potensi yang dimilikinya. Artinya guru harus mampu mengelola kegiatan pembelajaran, mulai dari merencanakan, melaksanakan, dan mengevaluasi kegiatan pembelajaran. Guru harus menguasi manajemen kurikulum, mulai dari merencanakan perangkat kurikulum, melaksanakan kurikulum, dan mengevaluasi kurikulum, serta memiliki pemahaman tentang psikologi pendidikan, terutama terhadap kebutuhan dan perkembangan peserta didik 
agar kegiatan pembelajaran lebih bermakna dan berhasil guna

Menurut Syaiful (2009: 32), guru yang mempunyai kompetensi pedagogik akan mampu menciptakan lingkungan belajar efektif, menyenangkan dan akan lebih mampu mengelola kelas. Kemampuan guru mengelola kelas meliputi (1) pemahaman wawasan guru akan landasan dan filsafat pendidikan (2) guru memahami potensi dan keberagaman peserta didik, sehingga dapat didesain strategi pelayanan belajar sesuai keunikan masing-masing peserta didik (3) guru mampu mengembangkan kurikulum atau silabus baik dalam bentuk dokumen maupun implementasi dalam bentuk pengalaman belajar, (4) guru mampu menyusun rencana dan strategi pembelajaran berdasarkan standar kompetensi dan kompetensi dasar, (5) mampu melaksanakan pembelajaranpembelajaran yang mendidik dengan interaktif. Sehingga pembelajaran menjadi aktif, inovatif, kreatif, efektif, dan menyenangkan, (6) mampu melakukan evaluasi hasil belajar dengan memenuhi prosedur dan standar yang dipersyaratkan (7) mampu mengembangkan bakat dan minat peserta didik melalui kegiatan ekstra kurikuler dan intrakulikuler untuk mengaktualisasikan berbagai potensi yang dimiliki

b. Pelaksanaan Program Inovasi
1) Kegiatan

Kegiatan Lesson Study dilakukan pada saat proses pembelajaran berlangsung. Kegiatan Lesson Study dilakukan dalam tiga tahap atau tiga kali pertemuan. Setiap pertemuan merangkup tiga kegiatan, yang biasa disebut dengan Plan-Do-See adapun langkah-langkah Plan-Do-See secara rinci adalah sebagai berikut.

a) Tahap Plan, meliputi:

(1)Sebelum guru melakukan pembelajaran di kelas, secara bersama-sama guru satu rumpun membahas tentang pembuatan RPP, saol evaluasi dan model pembelajaran yang cocok untuk digunakan.

(2)Secara bersama-sama membahas permasalahan di dalam kelas untuk memberikan gambaran permasalahan yang ada.

(3)Membahas pembuatan Lembar kerja siswa,

(4)Secara bersama-sama membuat kisikisi soal serta soalnya untuk UH, Mid semester atau semester

b) Tahap Do meliputi:

(1) Guru model melaksanakan pembelajaran yang berpusat pada siswa (sesuai dengan yang direncanakan).

(2) Guru lain mengobservasi aktivitas belajar siswa. 
Hal yang perlu diperhatikan oleh observer:

(a) Observer tidak boleh berinteraksi dengan siswa yang sedang belajar ataupun dengan guru yang sedang melakukan proses pembelajaran.

(b) Sesama observer dilarang mengobrol atau interaksi lainya

(c) Observer mencatat temuan/hal yang menarik dari proses pembelajaran, dituangkan dalam lembar observasi.

(d) Dokumentasi: Daftar hadir, lembar observasi, foto kegiatan, rekaman video jika memungkinkan.

c) Tahap See meliputi:

1) Dengan prinsip kolegialitas secara kolaboratif merefleksi efektivitas pembelajaran dan saling belajar.Hal yang perlu diperhatikan pada tahap See yakni:

(a) Sebaiknya tahap See dilaksanakan setelah pembelajaran selesai, tidak boleh rentang waktu yang lama.

(b) Pada tahap See dipimpin oleh seorang moderator

(c) Guru model diberi kesempatan untuk menyampaikan perasaannya atas apa yang telah dilaksanakan pada proses pembelajaran.

\section{KESIMPULAN}

Berdasarkan hasil dan pembahasan penelitian tentang pembelajaran Lesson Study maka dapat disimpulkan bahwa :

1. Lesson Study bukan metode pembelajaran, tetapi kebiasaan/pekerjaan Bapak/Ibu guru untuk meningkatkan keprofesionalan guru melalui learning community

2. Pembelajaran Lesson Study dapat meningkatkan kesiapan guru dalam melakukan proses pembelajaran.

3. Pembelajaran Lesson Study membantu guru mengetahu kelamahan-kelamahan dalam dirinya khususnya kemapuan bidang pedagogik, sehingga dipertemuan berikutnya dapat ditingkatkan.

Berdasarkan hasil penelitian, pembahasan, dan kesimpulan disarankan sebagai berikut :

1. Kepala sekolah yang berkeinginan untuk meningkatkan kemampuan pedagogik guru sebaiknya menggunakan pembelajaran Lesson Study

2. Guru yang ingin meningkatkan kemampuan dalam menyampaikan materi di kelas dapat menggunakan pembelajaran Lesson Study 


\section{DAFTAR PUSTAKA}

Astika .2013. Efektivitas Diklat Lesson Study Terhadap Peningkatan Kompetensi Profesional, Kompetensi Pedagogi Guru, Dan Prestasi Belajar Siswa Sma Negeri 3 Singaraja: Universitas Pendidikan Ganesha Singaraja, Indonesia

Ani M. Hasan. (2003). Pengewbangan Profesionalisme Guru di Abaci Pertengahan. (online) tersedia HTTPJ/artikel.ns/ A M Hasan. Html (13 maret 2014)

Hendayana, S. dkk. 2006. Lesson study Suatu Strategi Untuk Meningkatkan Keprofesionalan Pendidikan (Pengalaman IMSTEP-JICA). Bandung: UPI Press. S. dkk. 2007. Lesson Study Suatu Startegi Untuk Meningkatkan Keprofesionalan Pendidik, Bandung: FPMIPA UPI dan JICA.

Hidayat, Boby. 2015. Micro Teaching

Berbasis Lesson Study. Laboratorium Micro Teaching: FKIP UM Metro Mentri Pendidikan Nasional. 2007. Standar Kualifikasi Akademik dan Kompetensi Guru.

Mulyana, S. 2007. Lesson Study (Makalah). Kuningan: LPMP-Jawa Barat Rusman. 2010. Model-model Pembelajaran Mengembangkan
Profesionalisme Guru, Jakarta: PT Raja Grafindo.

Susilo dkk. 2009. Lesson Study Berbasis Sekolah. Malang: Bayumedia Publishing

Syaiful, Sagala. 2009. Kemampuan Profesional Guru dan Tenaga Kependidikan, Bandung: Alfabeta.

UU Sisdiknas No. 20 Tahun 2003. Tentang Sistem Pendidikan Nasional. Jakarta : Sinar Grafika.

Yoshida, M., \& Fernandez, C. 2004. Lesson Study: A Japanese Approach to Improving Mathematics Teaching and Learning. New Jersey: Lawrence Erlbaum Associates. 